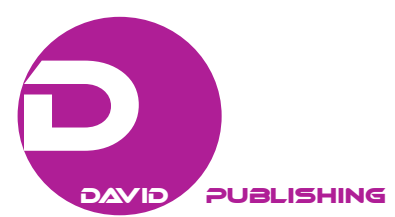

\title{
Integration Level for the Association of Southeast Asian Nations (ASEAN) Economic Community
}

\author{
Sylvia Cristina Alvarado Navas \\ Free Lancer, Jakarta, Indonesia
}

\begin{abstract}
The time has come for the constitution of the Association of Southeast Asian Nations (ASEAN) economic community and many facts have been analyzed regarding this topic. This paper presents the results of the statistical analysis applied to several economic parameters which firstly show how their integration pattern adjusts with a considerable good fitting to the optimum currency area model and to its extended version by Behrens; and secondly how the 10 members of this group are moving at relatively same speed in spite of their differences, that are also inferred for ranging.
\end{abstract}

Keywords: Association of Southeast Asian Nations (ASEAN), regional integration, ASEAN members' economic differences and similarities, currency harmonization, optimum currency area (OCA)

\section{Introduction}

It is interesting to estimate the degree of the economic integration of this association of countries when the economic community shall be established, in order to have a reference to evaluate the current situation and also to observe afterwards the real benefits and the exchange tendencies of several economic parameters. With this purpose, this paper contains a general review of the Association of Southeast Asian Nations' (ASEAN's) origins and aims, as well as the theory to support the chosen techniques.

\section{ASEAN's Will of Becoming an Economic Community}

The ASEAN was established on 8 August, 1967 and its member states are Brunei Darussalam, Cambodia, Indonesia, Lao PDR, Malaysia, Myanmar, Philippines, Singapore, Thailand, and Vietnam. Pike (2011) wrote that their integration process started a few years before in 1961 with the Association of South East Asia (ASA).

The fifth purpose for this association, article 1 of the ASEAN Charter (Association of the Southeast Asian Nations [ASEAN], 2007), was to create a single market and production base that would be stable, prosperous, highly competitive, and economically integrated with effective facilitation for trade and investment in which there is free flow of goods, services, and investment; facilitated movement of business, persons, professionals, talents, and labor; and free flow of capital.

The members drew up the roadmap for the ASEAN community 2009-2015 (ASEAN, 2009); and one of the main areas was the economic community (AEC), where the leaders affirmed in the Blueprint their strong

Sylvia Cristina Alvarado Navas, food engineer and magister in economic foreign affairs, free lancer, Jakarta, Indonesia.

Correspondence concerning this article should be addressed to Sylvia Cristina Alvarado Navas, Calle Menéndez Pelayo No. 121 y Barcelona. Ciudadela España. Ambato, 180101, Ecuador. 
commitment to accelerate the establishment of the community by 2015 . They particularly agreed to hasten the establishment of the AEC by 2015 and to transform ASEAN into a region with free movement of goods, services, investment, skilled labor, and free flow of capital.

The Fact Sheet published by the ASEAN (2013) mentioned that the ASEAN AEC will bring benefits to the peoples of ASEAN by creating a more conducive environment through transparency, predictability, and consistency for business to flourish. This will in turn benefit consumers who will have access to a cheaper and wide range of goods and services and enjoy more extensive consumer protection. Additionally, it indicates that the newer ASEAN member states of Cambodia, Lao PDR, Myanmar, and Viet Nam stand to also gain through the many opportunities for production networks created by an AEC and the productivity enhancing effects of AEC's emphasis on best practices.

The referred document also resumes the aims to achieve the AEC by facilitating free flow for goods, services, investments, and skilled labor, and free flow of capital increasing physical, institutional, and people-to-people connectivity to bring down the cost of doing business; narrowing the development gap both within and among the ASEAN member states by instituting targeted programs; and finding synergy trough engaging in bilateral Free Trade Agreements (FTAs) and consolidating the Plus One FTAs into a regional comprehensive economic partnership (RCEP). Further, this level will be reached by tracking the progress and performance against set targets through the AEC score cared mechanism.

\section{Economic Integration in Terms of Currency Harmonization}

According to Mundell (1961), a high degree of production factors mobility in a region may favor a single currency area. Based on this theory, Bayoumi and Eichengreen (1997) developed a model in order to study the feasibility of the monetary unification for the European Community as the deepest level of economic integration.

The referred model developed an index called optimum currency area (OCA) as a measure of the synchronization in the exchange rates as a function of four variables: real output differences, dissimilitude in merchandise trade, fraction of exports in gross domestic product (GDP), and size of the economies.

These kinds of models have become popular to evaluate the integration of other regions around the world, although originally the results were thought to reflect the economic integration level prior to the adoption of a single currency and that reaches the delicate implications of seigniorage like work of Alesina and Barro (2002).

OCA equations were applied to study the Asian countries by several authors: Lee, Park, and Shin (2003); Ogawa and Kawasaki (2007); Falianty (2008); Han and Lee (2010); Achsani and Partisiwi (2010); Volz (2010); Kawasaki (2012); Lee and Azali (2012); Shimizu (2013); Thiumsak (2014); and Alvarado (2014a; 2014b).

Ramírez (2011) used Bayoumi and Eichengreen's model (1997) to evaluate the integration in Latin America. Behrens (2015) applied the same model and even extended it to study the UNASUR and this modified model is considered for the present study, but, with the introduction of some variations.

\section{Inferring Differences and Similarities Among the Members}

Different statistical techniques could be used to study a group through parameters or indicators which in this case are economic, for instance, Khan P. Ngo (2012) cited by Thiumsak (2014) and Alvarado (2014a) 
applied the least significant difference technique to enrich the research of the members of the ASEAN, that method starts with the analysis of variance-ANOVA.

In the present study after the variance determination of the considered economic parameters instead of the least significant difference, the Duncan's multiple range tests (1995) were performed in order to define subgroups in the ASEAN and visualize the symmetries and asymmetries.

Although the orthodox economistic analysis may be considered irrelevant for some authors like Jones (2015) in terms of the real advances that have been made to in fact achieve AEC in this moment, they do not pretend to be recommendations but show the actual situation of this association.

\section{OCA Models}

The model proposed by Bayoumi and Eichengreen (1997) for the European Community is represented in equation (1) and the obtained coefficients are included in Table 1.

$$
S D\left(e_{i j}\right)=\alpha+\beta_{1} S D\left(\Delta y_{1}-\Delta y_{j}\right)+\beta_{2} \operatorname{DISSIM}_{i j}+\beta_{3} T R A D E_{i j}+\beta_{4} S I Z E_{i j}
$$

where $S D\left(e_{i j}\right)$ is the standard deviation of the change in the logarithm of the end-year bilateral exchange rate between countries $i$ and $j$; $S D\left(\Delta_{i}-\Delta_{j}\right)$ is the standard deviation of the difference in the logarithm of real output between $i$ and $j$ and aims to measure the output disturbances' effect; DISSIM $i j$ is the sum of the absolute differences in the shares of agricultural, mineral, and manufacturing trade in total merchandize trade of countries $i$ and $j$ and reflects the external shock influence according to the exports composition; TRADE $E_{i j}$ is the mean of the ratio of bilateral exports to domestic GDP for the two countries and it is used to measure intraregional trade linkages; and $S I Z E_{i j}$ is the mean of the logarithm of the two GDPs measured in US dollars and shows the influence of the country size.

Behrens (2015) based on equation (1) developed equation (2) in order to expand the model when researching the prerequisites for a monetary union in UNASUR.

$$
S D\left(e_{i j}\right)=\alpha+\beta_{1} S D\left(\Delta y_{1}-\Delta y_{j}\right)+\beta_{2} \operatorname{DISSIM}_{i j}+\beta_{3} T R A D E_{i j}+\beta_{4} \operatorname{SIZE}_{i j}+\beta_{5} U N E M P_{i j}+\beta_{6} P R I C E_{i j}
$$

where the variables are the same of the equation (1) except $U N E M P_{i j}$ is computed as the mean of the logarithm of the absolute value of the differences between the unemployment rates between countries $i$ and $j$ and is included as the measure of the integration and flexibility of the countries' labor markets; and $P R I C E_{i j}$ is calculated as the mean of the logarithm of the absolute value of the differences between the inflation rates of consumer prices between countries $i$ and $j$ and it is a measure of the integration in goods' market.

In the present paper, $U N E M P_{i j}$ and $P R I C E_{i j}$ values correspond to the standard deviation for the period, of the logarithm of the absolute bilateral differences between countries $i$ and $j$; introducing in this way the measurement of the bilateral variation of these rates through the time, modifying in this way Behrens' proposal (2015) for the labor and goods' markets.

Data sources and calculations are as follows:

- The quarterly exchange rates, for each country in Special Drawing Rights (SDR), reported by the International Monetary Fund (Retrieved from http://www.imf.org/external/np/fin/data/rms_sdrv.aspx) except for Philippine Peso, Lao Kip, Burmese Kyat, and Vietnamese Dong found at the World Favorite Currency Site XE (Retrieved from http://www.xe.com/currencytables/?from=PHP\&date=2005-03-15); were used to 
determine the annual average, then the bilateral rate expressed in logarithms and its change, and, finally the standard deviation value of the period $S D\left(e_{i j}\right)$;

- GDP values retrieved from the World Bank (except for Myanmar-IMF; Retrieved from http:/data. worldbank.org/indicator/SP.POP.TOTL) were used to calculate the real output of the countries expressed in logarithms, afterwards the bilateral differences were determined and the standard deviation of the period $S D\left(\Delta_{i}-\Delta_{j}\right)$

- The shares of agricultural, mineral, and manufacturing trade in total merchandize trade calculated by the World Trade Organization (WTO, Retrieved from https://www.wto.org/english/res_e/statis_e/statis_bis_e.htm? solution=WTO\&path=/Dashboards/MAPS\&file=Map.wcdf\&bookmarkState $=\{\% 22 \mathrm{impl} \% 22: \% 22 \mathrm{client} \% 22, \%$ 22params\%22:\{\%22langParam\%22:\%22en\%22\}\}) were used to stablish the absolute bilateral differences as a sum for all the period; Lao PDR data were calculated with the observatory of economic complexity data and Myanmar values 2005-2007 are the same than the ones of 2008;

- The bilateral exports values are reported by the Observatory of Economic Complexity (Retrieved from http://atlas.media.mit.edu/en/visualize/tree_map/hs92/export/bra/show/all/2013/) with these and the GDP figures by the World Bank (Retrieved from http://data.worldbank.org/indicator/SP.POP.TOTL); TRADE $i j$ was calculated as the period mean of the fraction of total bilateral exports over the total GDP;

- For determining $S I Z E_{i j}$ data, the GDP values were expressed in logarithms, to calculate the bilateral average of the period;

- $U N E M P_{i j}$ corresponds to the period's mean of the bilateral absolute differences of the unemployment rates that were retrieved from the World Bank web site (Retrieved from http://data.worldbank.org/indicator/SP. POP.TOTL). For the present calculation, the absolute values of the bilateral differences are expressed in logarithms, and then the standard deviation of the period is measured;

- $P R I C E_{i j}$ is the period's mean of the bilateral absolute differences of the inflation rate for consumer price. Data were retrieved from the World Bank (Retrieved from http://data.worldbank.org/indicator/SP.POP.TOTL). For this study, the absolute bilateral differences are expressed in logarithms then the standard deviation of the period is determined.

\section{Multiple Comparison Tests}

When applying the ANOVA test with a positive result, meaning that at least one of the groups differs from the others; Duncan's multiple range tests (1995) have been chosen as far as considering several critical differences and allowing stablishing sets of similar countries, according to each economic indicator based on equation (3) (Saltos, 1993).

$$
Y_{i}-Y_{j}>d \sqrt{M S E / n}
$$

where $Y_{i}-Y_{j}$ is the bilateral difference of the averages for each economic indicator; $d$ is critical value proposed by Duncan (1995) — one for each range at 0.05; MSE is the mean square error from the ANOVA test; and $n$ is the number of scores used to calculate the means.

The sources of information are: World Bank for GDP, population, unemployment rates, and inflation rates; OEC and COMTRADE (Retrieved from http://comtrade.un.org/data/) for the bilateral exports values; and WTO for total exports by country. 


\section{Results of OCA Models}

Table 1 encloses the coefficients for equation (1) reported by Bayoumi and Eichengreen (1997) when studying the European countries and the ones of the present analysis for the ASEAN countries for the decade 2004-2013, also the ones for equation (2) reported by Behrens (2015) for UNASUR, and the ones estimated in this research for ASEAN 2004-2014.

Table 1

Coefficients for Optimum Currency Area Equations

\begin{tabular}{|c|c|c|c|c|}
\hline & $\begin{array}{l}\text { Bayoumi and Eichengreen } \\
\text { (1997) }\end{array}$ & Present study & Behrens (2015) & Present study \\
\hline & \multicolumn{2}{|c|}{ OCA MODEL } & \multicolumn{2}{|c|}{ OCA EXTENDED } \\
\hline & $\begin{array}{l}\text { European Union } \\
21 \text { countries } \\
\end{array}$ & $\begin{array}{l}\text { ASEAN } \\
10 \text { countries }\end{array}$ & $\begin{array}{l}\text { UNASUR } \\
12 \text { countries }\end{array}$ & $\begin{array}{l}\text { ASEAN } \\
10 \text { countries }\end{array}$ \\
\hline & 1983-1992 & 2004-2013 & $1996-2007$ & 2004-2013 \\
\hline Samples & 210 & 45 & 132 & 45 \\
\hline Significance & & $<0.001$ & 0.392 & $<0.001$ \\
\hline$R^{2}$ & 0.51 & 0.6844 & 0.048 & 0.7635 \\
\hline Stand. Err. & 0.027 & 0.0082 & 0.1204 & 0.0060 \\
\hline “ $\alpha "$ & -0.09 & 0.0140 & -0.201 & -0.0323 \\
\hline Stand. Err. & 0.02 & & 0.143 & \\
\hline Significance & & & 0.164 & \\
\hline “ $\beta_{1} "$ & 1.46 & 0.0405 & -0.404 & 0.0361 \\
\hline Stand. Err. & 0.021 & 0.0081 & 0.395 & 0.0061 \\
\hline Significance & & 0.0000 & 0.307 & 0.0000 \\
\hline “炽" & 0.022 & -0.0010 & 0.051 & -0.0011 \\
\hline Stand. Err. & 0.006 & 0.2029 & 0.034 & 0.1421 \\
\hline Significance & & 0.0063 & 0.139 & 0.0000 \\
\hline “乾” & -0.054 & -0.1661 & 0.226 & -0.3439 \\
\hline Stand. Err. & 0.006 & 0.0010 & 0.930 & 0.0007 \\
\hline Significance & & 0.0235 & 0.809 & 0.0000 \\
\hline “ $\beta_{4} "$ & 0.012 & 0.0001 & 0.016 & 0.0044 \\
\hline Stand. Err. & 0.001 & 0.2357 & 0.013 & 0.0138 \\
\hline Significance & & 0.9702 & 0.200 & 0.0936 \\
\hline “ $\beta_{5} "$ & & & 0.018 & 0.0223 \\
\hline Stand. Err. & & & 0.018 & 0.0039 \\
\hline Significance & & & 0.327 & 0.1961 \\
\hline “梠” & & & 0.003 & 0.0023 \\
\hline Stand. Err. & & & 0.016 & 0.0177 \\
\hline Significance & & & 0.839 & 0.2599 \\
\hline
\end{tabular}

The OCA values are the pairs of countries in Table 2 in bold that are ready to converge, in italic that are the ones show tendency, and the rest are according to Bayoumi and Eichengreen's method (1997). 
Table 2

Optimum Currency Area (OCA) Indexes Calculated for ASEAN Countries With Equations (1) and (2)

\begin{tabular}{|c|c|c|c|c|c|c|c|c|c|c|c|}
\hline \multicolumn{6}{|c|}{ Equation (1) } & \multicolumn{6}{|c|}{ Equation (2) } \\
\hline Pair & OCA & Pair & OCA & Pair & OCA & Pair & OCA & Pair & OCA & Pair & OCA \\
\hline MS & 0.0017 & $C L$ & 0.0186 & IL & 0.0257 & MS & -0.011 & MP & 0.0187 & IT & 0.0271 \\
\hline$B M$ & 0.0119 & $L S$ & 0.0188 & NT & 0.0258 & $M T$ & 0.0075 & LS & 0.0188 & $\mathrm{CN}$ & 0.0277 \\
\hline$M T$ & 0.0140 & $T V$ & 0.0196 & NP & 0.0262 & $B T$ & 0.0132 & PT & 0.0188 & $\mathrm{CS}$ & 0.0277 \\
\hline$B S$ & 0.0140 & $M P$ & 0.0199 & IT & 0.0269 & $S T$ & 0.0146 & $\mathrm{CL}$ & 0.0200 & NP & 0.0277 \\
\hline$L V$ & 0.0144 & $C V$ & 0.0202 & NS & 0.0270 & BS & 0.0152 & $\mathrm{LT}$ & 0.0202 & $\mathrm{CM}$ & 0.0290 \\
\hline$L T$ & 0.0156 & MV & 0.0213 & IV & 0.0270 & BM & 0.0156 & TV & 0.0205 & IV & 0.0300 \\
\hline$B T$ & 0.0156 & IS & 0.0219 & $\mathrm{BN}$ & 0.0282 & BV & 0.0157 & MV & 0.0212 & NS & 0.0307 \\
\hline$S T$ & 0.0165 & $\mathrm{BC}$ & 0.0225 & $\mathrm{CS}$ & 0.0285 & BP & 0.0159 & $\mathrm{BL}$ & 0.0213 & IP & 0.0312 \\
\hline$P V$ & 0.0166 & IP & 0.0226 & $\mathrm{CM}$ & 0.0294 & LV & 0.0163 & $\mathrm{CV}$ & 0.0224 & $\mathrm{LN}$ & 0.0313 \\
\hline$P T$ & 0.0169 & $\mathrm{CT}$ & 0.0232 & $\mathrm{CN}$ & 0.0309 & IS & 0.0166 & NT & 0.0241 & IM & 0.0316 \\
\hline$S V$ & 0.0170 & $\mathrm{CP}$ & 0.0239 & $\mathrm{NV}$ & 0.0317 & PS & 0.0170 & LM & 0.0245 & $\mathrm{BN}$ & 0.0318 \\
\hline$L P$ & 0.0173 & LM & 0.0247 & IM & 0.0321 & SV & 0.0170 & $\mathrm{CP}$ & 0.0247 & $\mathrm{NV}$ & 0.0325 \\
\hline$B V$ & 0.0175 & $\mathrm{BL}$ & 0.0249 & $\mathrm{LN}$ & 0.0328 & LP & 0.0172 & $\mathrm{CI}$ & 0.0250 & $\mathrm{MN}$ & 0.0330 \\
\hline$B P$ & 0.0181 & $\mathrm{MN}$ & 0.0252 & $\mathrm{BI}$ & 0.0349 & $\mathrm{BC}$ & 0.0174 & $\mathrm{CT}$ & 0.0259 & BI & 0.0347 \\
\hline$P S$ & 0.0186 & $\mathrm{CI}$ & 0.0256 & IN & 0.0448 & PV & 0.0182 & IL & 0.0266 & IN & 0.0488 \\
\hline
\end{tabular}

\section{Results of Multiple Comparison Tests}

When comparing the speed of changing of all the considered economic indicators, no significant differences were found for neither of them; although the members of ASEAN are indeed different when talking about GDP, population, GDP per capita, exports to ASEAN vs. total exports, unemployment rate, and inflation rate; and with these results, subgroups were drawn like superposed stair that can be observed in Table 3 . The level of $F$ used for the analysis was 0.05 .

Table 3

Subgroups of Countries According to Duncan's Range Tests

\begin{tabular}{|c|c|c|c|c|c|c|c|c|c|c|c|c|c|c|c|c|c|c|c|c|c|}
\hline \multicolumn{3}{|c|}{ GDP } & \multicolumn{5}{|c|}{ Population } & \multicolumn{4}{|c|}{ GDP per capita } & \multicolumn{5}{|c|}{ Exports ASEAN/total } & \multicolumn{3}{|c|}{$\begin{array}{l}\text { Unemployment } \\
\text { rate }\end{array}$} & \multicolumn{2}{|c|}{ Inflation rate } \\
\hline \multicolumn{3}{|c|}{ 2000-2014 } & \multicolumn{5}{|c|}{$2000-2014$} & \multicolumn{4}{|c|}{ 2000-2014 } & \multicolumn{5}{|c|}{ 2001-2013 } & \multicolumn{3}{|c|}{ 1999-2013 } & \multicolumn{2}{|c|}{$2000-2014$} \\
\hline $\mathrm{L}$ & & 3 & B & & & & & & $\mathrm{N}$ & & 4 & $\mathrm{C}$ & & & & 4 & $\mathrm{C}$ & & 4 & B & 3 \\
\hline $\mathrm{C}$ & & 3 & S & & & & 7 & & $\mathrm{C}$ & & 4 & V & & & 3 & 4 & $\mathrm{~T}$ & 3 & 4 & S & 3 \\
\hline $\mathrm{B}$ & & 3 & $\mathrm{~L}$ & & & & 7 & & $\mathrm{~L}$ & & 4 & S & & & 3 & 4 & $\mathrm{~L}$ & 3 & & M & 3 \\
\hline $\mathrm{N}$ & 2 & 3 & C & & & 6 & & & V & & 4 & $\mathrm{P}$ & & & 3 & 4 & V & 3 & & $\mathrm{~T}$ & 3 \\
\hline $\mathrm{V}$ & 2 & 3 & M & & & & & & $\mathrm{P}$ & & 4 & I & & & 3 & 4 & M & 2 & & $\mathrm{P}$ & 3 \\
\hline $\mathrm{P}$ & 2 & & $\mathrm{~N}$ & & 4 & & & & I & 3 & 4 & $\mathrm{~T}$ & & & 3 & 4 & $\mathrm{~N}$ & 2 & & C & 3 \\
\hline $\mathrm{S}$ & 2 & & $\mathrm{~T}$ & 3 & & & & & $\mathrm{~T}$ & 3 & 4 & B & & 2 & 3 & & B & 2 & & I & 2 \\
\hline $\mathrm{M}$ & 2 & & V & 2 & & & & & $\mathrm{M}$ & 3 & & $\mathrm{M}$ & & 2 & 3 & & $S$ & 2 & & V & 2 \\
\hline $\mathrm{T}$ & 2 & & $\mathrm{P}$ & 2 & & & & & B & 2 & & $\mathrm{~N}$ & 1 & 2 & & & $\begin{array}{ll}\text { I } & 1\end{array}$ & & & $\mathrm{~L}$ & 2 \\
\hline $\begin{array}{ll}\text { I } & 1\end{array}$ & & & I & & & & & & $\mathrm{S}$ & & & L & 1 & & & & & & & $\mathrm{~N}$ & \\
\hline
\end{tabular}

Notes. B-Brunei Darussalam, C-Cambodia, I-Indonesia, L-Lao PDR, M-Malaysia, N-Myanmar (Burma), $\mathrm{P}$-Philippines, $\mathrm{S}$-Singapore, $\mathrm{T}$ - Thailand, and V-Viet Nam. 


\section{Discussion}

Analyzing Table 1, Behrens (2015) used twice the number of samples than expected according to Bayoumi and Eichengreen's method (1997). For the present analysis, the coefficients of determination are good, because $68 \%$ and $73 \%$ of the data fit equation (1) and equation (2) respectively and the standard error of the model is low.

Regarding the coefficients for the present research: " $\beta_{1}$ " have the expected positive sign and highly influence the dependent variable, because in the ASEAN case, the output disturbances explain the currency harmonization; " $\beta_{2}$ " relate to the dissimilitude in commerce explain the monetary approaching, but prove to have an inverse relation - contrary to expected, then higher differences correspond to lower OCA values; " $\beta_{3}$ " as expected have inverse and significant influence meaning that higher trade levels lead to exchange rate proximity; " $\beta_{4}$ " or sizes of the economies have a directly proportional relationship with the independent variable, but the significance level for equation (1) is very poor; and " $\beta_{5}$ " and " $\beta_{6}$ " up to a certain point significant to the model have positive sign showing that similar unemployment and similar inflation levels favor the monetary synchronization in ASEAN.

The OCA indexes - display in Table 2, have quite similar magnitude for all of the pairs, showing similar reaction of the exchange rates to the variation of all the independent values. Also because of that, the model standard error is quite small and the test to evaluate convergence is stricter than the one applied by Bayoumi and Eichengreen (1997). In the end, a good level of harmonization is evident.

Seeing the results reported in Table 3, the group of 10 draws a kind of scales with different superpositions for each index. It is evident that the deepest differences are found when referring to population, because it defines eight subgroups; but only four to unemployment rate, GDP per capita and exports to ASEAN; and just three to GDP and inflation rate. Distribution of subgroups could lead to observing the symmetries and asymmetries in the association and in such conditions; it is remarkable that there are no significant differences in the speed of changing of all these indicators for the ten members.

\section{Conclusions}

The results could be interesting in terms of evaluating the level of integration for the ASEAN AEC at this precise moment, by offering an idea of its evolution and its current situation, but it does not pretend to reach the recommendations level.

According to this study and in terms of integration, it is a fact that the economic theory of OCA in a region-proposed by Mundell (1961); later expressed by Bayoumi and Eichengreen (1997) in a model, extended by Behrens (2015), applies, and can explain what is happening in the ASEAN, where the currency synchronization is evident and indeed it is a proven function of the output disturbances, the dissimilarities of the exports composition, the intense of trade, the size of the economies, and also the labor and good market similarities.

Moreover, this outcome has been confirmed by using other statistical techniques which found a similar speed of change among the 10 members for the considered economic indicators in spite of their differences whose analysis led to drawing like superposed scales.

\section{References}

Achsani, N. A., \& Partisiwi, T. (2010). Teasing the feasibility of ASEAN+3 single currency comparing optimum currency are and clustering approach. Retrieved from http://achsani.blog.mb.ipb.ac.id/files/2010/08/irjfe_37_08.pdf 
Alesina, A., \& Barro, R. (2002). Currency unions. Quarterly Journal of Economics, 117(2), 409-436.

Alvarado, S. (2014a). Inference of the ASEAN integration towards AEC 2015. Proceedings from the 3rd International Conference on Business and Communication. Entrepreneurship Beyond Boundaries: Towards ASEAN Economic Community. Retrieved from http://icbc.atmajaya.ac.id/wp-content/uploads/2014/Proceedings_of_the_3rd_ICBC2014.pdf

Alvarado, S. (2014b). Analysis of the optimum currency area for ASEAN and ASEAN+3. Journal of US-China Public Administration, 11(12), 995-1004.

Association of the Southeast Asian Nations [ASEAN]. (2007). The ASEAN charter (15th reprint, ASEAN Secretariat, p. 53).

Association of the Southeast Asian Nations [ASEAN]. (2009). Road map for ASEAN community 2009-2015 (ASEAN, Cha-am, Thailand, p. 112).

Association of the Southeast Asian Nations [ASEAN]. (2013). ASEAN economic community (AEC) fact sheet (2nd reprint, Jakarta, ASEAN Secretariat, p. 4).

Bayoumi, T., \& Eichengreen, B. (1997). Ever closer to heaven? An optimum-currency-area index for European countries. European Economic Review, 41, 761-770.

Behrens, L. (2015). Prerequisites for creating a monetary union in UNASUR. A discussion on the basis of the optimum currency area theory (AkademikerVerlang.Saarbrücken, Germany).

Duncan, D. (1955). Multiple range and multiple F tests. Biometrics, 11, 1-42.

Falianty, T. A. (2008). Feasibility of forming currency union in ASEAN-5 countries. Retrieved from http://staff.ui.ac.id/system/files/users/telisa.aulia/publication/currencyuniontelisa.pdf

Han, K., \& Lee, Y. (2010). East Asian monetary integration and the composite index of OCA criteria. Korean and the World Economy, 11(2), 297-339.

International Monetary Fund. Currency unites per special drawing rights (SDR) for ASEAN countries $2002-2013$ [Data file]. Retrieved from http://www.imf.org/external/np/fin/data/rms_sdrv.aspx

Jones, L. (2015). Explaining the failure of the ASEAN economic community: The primacy of domestic political economy. Retrieved from https://www.academia.edu/13451027/Explaining_the_Failure_of_the_ASEAN_Economic_Community_The_Primacy_ of Domestic_Political_Economy

Kawasaki, K. (2012). Are the ASEAN plus three countries coming closer to an OCA. Retrieved from http://www.rieti.go.jp/en/publications/summary/12050008.html

Lee, G., \& Azali, M. (2012). Is East Asia an optimum currency area? Economic Modelling, 29(2), 87-95.

Lee, J., Park, Y., \& Shin, K. (2003) A currency Union in East Asia (ISER discussion paper No. 571). Retrieved from http://ssrn.com/abstract $=396260$

Mundell, A. R. (1961). A theory of optimum currency areas. American Economic Review, 51(4), 657-665.

Ogawa, E., \& Kawasaki, K. (2007). East Asian currency cooperation. Retrieved from $\mathrm{http} / / /$ aric.adb.org/pdf/seminarseries/SS10paper_East_Asian_Currency.pdf

Pike, F. (2011). Empires at war. A short history of modern Asia since World War II. London: I. B. Tauris \& Co. Ltd.

Ramírez, X. (2011). The Latin America integration processes: Comparative analysis from the optimal currency areas theory. Retrieved from http://www.tdx.cat/bitstream/handle/10803/9315/Tesis_XRR_\%2810-12-13\%29.pdf?sequence=2

Saltos, H. A. (1993). Experimental design. Ecuador: Editorial Pio XII.

Shimizu, K. (2013). Regional cooperation for financial and exchange rates stability in East Asia. Retrieved from http://www.swp-berlin.org/fileadmin/contents/products/arbeitspapiere/WP_FG7_2013_01_Dezember_Kenichi_Shimizu.pdf

The Observatory of Economic Complexity [OEC]. Bilateral exports to the members of UNASUR period 2004-2012 [Data file]. Retrieved from http://atlas.media.mit.edu/en/visualize/tree_map/hs92/export/bra/show/all/2013/

The Observatory of Economic Complexity [OEC]. Bilateral exports to the members of UNASUR period $2004-2012$ [Data file]. Retrieved from http://atlas.media.mit.edu/en/visualize/tree_map/hs92/export/bra/show/all/2013/

The World Favorite Currency Site (XE). Historical rate tables for Philippine Peso (2004-2010), for Lao Kip, Burmese Kyat and Vietnamese Dong [Data file]. Retrieved from http:/www.xe.com/currencytables/?from=PHP\&date=2005-03-15

Thiumsak, T. (2014). The feasibility of optimal currency area for ASEAN after adopting the ASEAN economic community blueprint in 2008. Does it facilitate the region to move closer to a single currency area? Retrieved from http://lup.lub.lu.se/luur/download?func=downloadFile\&recordOId=4457848\&fileOId=4457859

United Nations. Department of Economic and Social Affairs. Statistics Division. Trade Statistics. Bilateral export values for the members of UNASUR year 2013. [UN COMTRADE Data file]. Retrieved from http://comtrade.un.org/data/ 
Volz, U. (2010). The standard approach: The theory of optimum currency areas (Prospects for monetary cooperation and integration in East Asia, Masachusetts Institute of Technology, USA, pp. 49-102).

World Bank. Gross domestic product, population, unemployment rates, inflation rates for consumer price [Data file]. Retrieved from http://data.worldbank.org/indicator/SP.POP.TOTL

World Trade Organization [WTO]. Merchandise exports by country and shares in total exports by commodity group 2004-2013 [International trade and market access data interactive tool]. Retrieved from https://www.wto.org/english/res_e/statis_e/statis_bis_e.htm?solution=WTO\&path=/Dashboards/MAPS\&file=Map.wcdf\&bo okmarkState $=\{\% 22$ impl $\% 22: \% 22$ client $\% 22, \% 22$ params $\% 22:\{\% 22$ langParam $\% 22: \% 22$ en $\% 22\}\}$ 